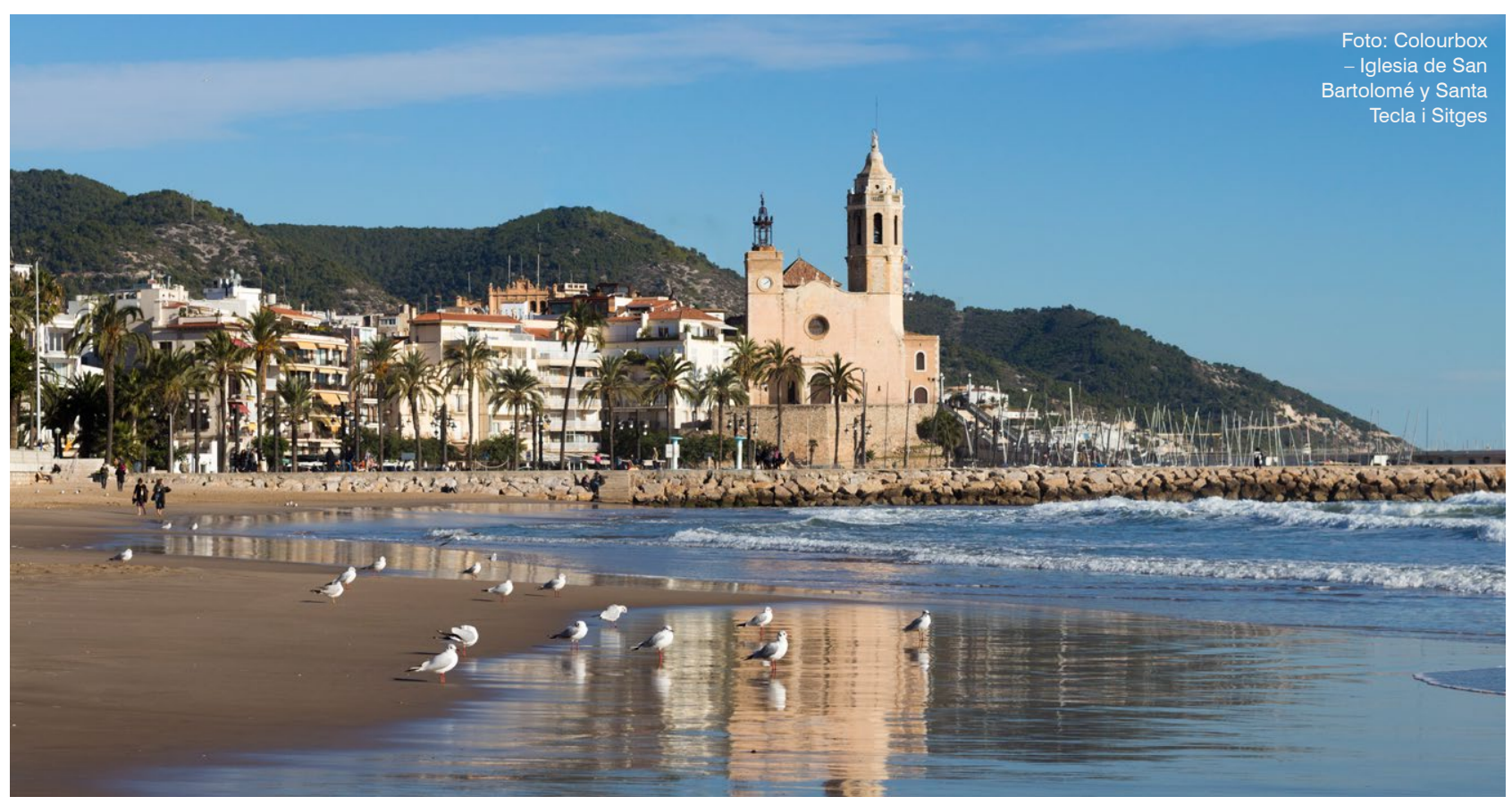

\title{
Nytenkning om borderline personlighetsforstyrrelse
}

\author{
Av Ina Bekkevold-Jernberg
}

\section{Nye perspektiver var målet når forskere og klinikere fra hele verden samlet seg under 5. internasjonale kongress om borderline personlighetsforstyrrelse og relatert problematikk.}

5. INTERNASJONALE KONGRESS om borderline personlighetsforstyrrelse og relatert problematikk ble arrangert fra 27.-29. september 2018 i Sitges, Spania. Tema var «Rethinking Borderline Personality Disorder: improving treatment and training».

Giennom i underkant av tre hele dager og med mer enn 650 deltakere fra 43 nasjoner ble et bredt og stødig program presentert som dekket de aller fleste aspekter innen borderline personlighetsforstyrrelse (BPD) og relatert problematikk.

Kongressens mål og tema var nytenkning og det var tydelig at innovasjon hadde en plass på programmet. Martin Bohus (Tyskland) fortalte om Virtual Reality-eksperimenter og nevrobio- logi for BPD, hyposensitivitet for positive følelser blant pasienter med BPD, og viser til forskning på kutting blant BPD-pasienter og hvordan det hielper dem med å regulere ned amygdala.

Deltakerne fikk også se flere interessante og klinisk rettede diskusioner på scenen i auditoriet; om konsepter og behandling av BPD, om diagnostisering av barn og unge, og om behandling av traumer hos pasienter med BPD.

Hele 17 sesioner omhandlet Dialektisk atferdsterapi (DBT) og ulike varianter av denne evidensbaserte behandlingsformen for BPD, vi tok en prat med to av de større retningene eller prosjektene som ble presentert.

\section{Family Connections - hjelper folk å hjelpe seg selv}

Vi møtte Perry Hoffman, Marie-Paule de Valdivia and Beth McCrave fra Family Connections Program (FC) og Francheska Perepletchikova. Hoffman er en av grunnleggerne av dette psykoedukative kurset med 12 ukers varighet. FC er et kurs for deg med en nærstående med trekk fra BPD, emosjonell dyregulering og/eller selvskadingsatferd. Den nærstående er ikke nødvendigvis 
i behandling og formålet er å gi informasion, ferdighetstrening og støtte til de pårørende.

Kursets innhold fokuserer på typiske temaer for BPD og det ledes som oftest av pårørende som er trent som gruppeledere. Alan Fruzzetti og Perry Hoffman utviklet kurset på grunnlag av forskningen sin, i tillegg til sin utstrakte kliniske erfaring med personer med BPD og deres pårørende.

Kurset gir pårørende oppdatert informasion og forskning om BPD, om familiefunksioner, individuelle ferdigheter basert på DBT, familieferdigheter og i tillegg gir gruppen de pårørende en støttefunksion og et nettverk.

- Noe vi ofte hører er at de pårørende onsker hielp til å få sin nærstående i behandling, og de lurer på om vi kan hjelpe dem med det. Det er ikke målet her, målet er at den pårørende skal få støtte og hielp til å stå i relasionen, og bedre den. Men vi understreker også at når relasionen er bedre og de har verktøy til å håndtere stormene så er de også i en bedre posision til å hielpe og påvirke den nærstående til å oppsøke hielp.

De pårørende, kursdeltakerne, står i forskjellige relasioner - som ektefeller, foreldre, søsken og venner. De deles ikke opp i forskiellige grupper da erfaringen er at belastningen av å ha en nærstående med BPD er nokså lik uansett.

I USA kan man melde seg på kurset online, men det har ennå ikke blitt etablert i Norge.

Er du interessert i mer informasion om å bli gruppeleder eller vil bidra til å etablere kurset lokalt så kan du sende en mail til neabpd@aol. com eller lese mer om FC på www.borderlinepersonalitydisorder.com/familyconnections.

\section{DBT i Storbritannia - først og størst i Europa}

Michaela Swales er en av nestorene for DBT i Storbritannia der de siden 1997 har utdannet DBT-terapeuter. Dette har resultert i at over $35^{\circ}$ DBT-programmer har blitt etablert.

- Vi har rukket giøre oss en del erfaringer angående implementeringsutfordringer, og vi ser ofte at storre avdelinger forplikter seg til å utdanne DBT-terapeuter og å gi dem 1 1/2 dag i uken til å jobbe med DBT, som er kravet vårt. Vi ser dessverre at det ofte ikke følges opp, at terapeutene i teorien får den tiden, men at ikke andre oppgaver reduseres tilsvarende og det kan lede til at man som DBT-terapeut «brenner ut» og ikke orker å drive mer med DBT.

En annen utfordring vi ser mye av er at DBT-programmet er etablert og fungerer godt, men at antallet pasienter teamet kan behandle ikke står opp mot proposionen av pasienter som ønsker, trenger og kanskje til og med har rett på en spesialisert behandling. Jeg tror vi trenger flere naturalistiske studier på hvem som har nytte av hvilken behandling, vi kan nok også bli bedre på å vurdere alvorlighetsgrad av lidelsen

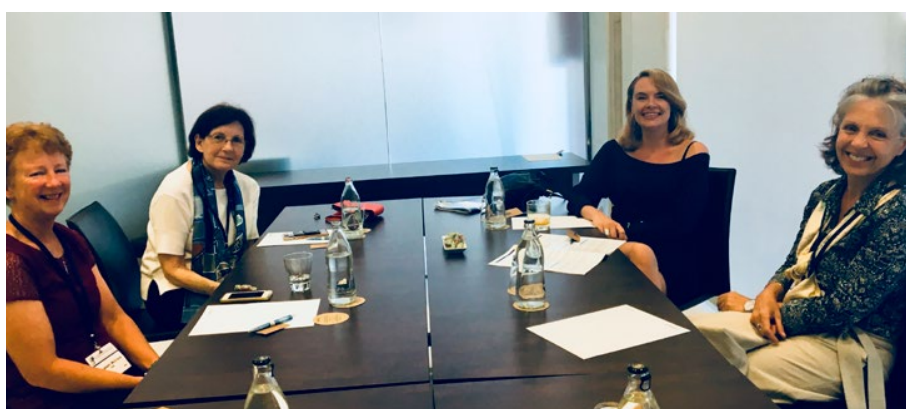

Fra venstre: Beth McCrave, Perry Hoffman, Francheska Perepletchikova og Marie-Paule de Valdivia. Foto: Ina Bekkevold-Jernberg

slik at vi vet mer om hvem som kan ha behov for hele DBT-programmet, og hvem som kan ha veldig god nytte av kun å få ferdighetstrening.

I Storbritannia ønsker de også å utvikle en adherenskoding av DBT som er mindre arbeidskrevende.

- Men det er jo begrenset hvor mange oppgaver man kan giøre på en gang, og jeg har i veldig mange år nå ventet på tidspunktet hvor etterspørselen etter DBT-utdanning går ned, men per nå så utdanner vi flere team enn noen gang.

Swales sitt team utdanner også DBT-terapeuter til å kun drive individualterapi i samarbeid med University of Bangor, et nokså nytt og omfattende utdanningstilbud.

\section{Et engasjert NSSF}

Professor og senterleder ved NSSF, Lars Mehlum, ble våren 2017 valgt til leder av European Society for the Study of Personality Disorders (ESSPD) som er arrangøren bak denne kongressen hvor Mehlum også var president.

NSSF var i tillegg representert på kongressen med følgende vitenskapelige presentasioner:

Lars Mehlum: Mechanisms of change during dialectical behaviour therapy (DBT) in suicidal and self-harming adolescents with borderline features - Oral presentation

Ruth-Kari Ramleth: Borderline criteria and self-harming behaviours in adolescents - do they covary over the longer term? - Oral presentation

Anita Johanna Tormoen: Adolescents with repeated suicidal and self-harming behaviour treated with Dialectical Behaviour Therapy and enhanced usual care: Ways of coping two years after treatment - Oral presentation

Ina Bekkevold-Jernberg: Age and gender differences in self-harm behaviours among patients with Borderline Personality Disorder - Oral presentation 